\title{
How Meat Science Academic Programming Can Facilitate Undergraduate and Graduate Student International Exposure
}

\author{
Keith E. Belk* \\ Department of Animal Science, Colorado State University, Fort Collins, CO 80523, USA \\ *Corresponding author. Email: keith.belk@colostate.edu (Keith E. Belk)
}

\begin{abstract}
As the world population increases and the trajectory of meat trade continues to expand across the borders of sovereign nations, it is important for university educators to increase the opportunities that undergraduate and graduate students have for engaging with other cultures. In the future, it is unlikely that students can be successful in a meat-based career without knowledge of the global markets. The Meat Science Group at Colorado State University have tried to offer such opportunities to students by engaging them in research; providing forums for exchange, internships, capacity building, and participating in international scientific meetings; and offering courses that assist students in their understanding of the global marketplace. As the world becomes a smaller place, all such student international activities are becoming a compulsory need to accommodate the Land Grant Mission.
\end{abstract}

Key words: international, students, travel, research, teaching

Meat and Muscle Biology 5(3): 3, 1-6 (2021) doi:10.22175/mmb.12617

Submitted 2 June $2021 \quad$ Accepted 18 June 2021

This paper was accepted as a contribution to the 2021 AMSA Reciprocal Meat Conference.

\section{Introduction}

Scientists have striven for many decades to extend their impact into international circles. Mechanisms for doing so have been diverse (e.g., refereed articles, international research collaboration, international project funding, etc.), and historically, those mechanisms often did not include opportunities for undergraduate and graduate students. Today, several options exist for involving students in international efforts, which affords them an opportunity to become more familiar with other cultures, beliefs, and behaviors - not to mention the opportunities to improve their disciplinary skills. Given growing global human populations and urban concentration, there is no downside to assisting students as they endeavor to understand other parts of their world.

Opportunities for students include participation in international research, scientific meetings, field trips, exchange programs, internships, capacity building and development, and pedagogy specifically designed to instill international skills and knowledge. On rare occasions, the opportunity to participate in some manner with bilateral and multilateral government-to-government negotiations also exist. These opportunities will be discussed in more depth in this paper.

Interestingly, international education and research objectives can differ dramatically depending on the mentor's philosophies, expertise, or interests. Many scientists work on Grand Challenge issues in an international format, whereas still others perform foreign assistance and capacity building work. But I will argue that the mission of Land Grant institution scientists should, at least partially, lead toward efforts to improve trade. If this is true, then students at Land Grant institutions simultaneously should also engage and learn about efforts to improve trade, as this is a direct benefit to them and the industries that they will serve in their state. For agricultural and meat trade, 
specifically, opportunities exist for student learning that directly impact product value and profitability. Likewise, those opportunities lead to a wide range of career choices. This paper also will outline in some detail these opportunities.

Whether students are just interested in the bottom line in the market sectors they serve or if they aspire to enter careers involving foreign negotiations or service to humanity, there is a growing need for institutions of higher learning to promote training in these fields. This is even more true in the livestock and meat trade. This paper considers options for improving international exposure for undergraduate and graduate students that truly expands their awareness and knowledge of other cultures to facilitate agricultural success.

\section{Involvement of Students Through Research}

Green (2019) defined "Global Learning" as "learning to live and work effectively and ethically in our interconnected and interdependent world." Such exposure for students is sometimes difficult and expensive, but one of the best ways to accomplish this is to involve students in international research. Involvement in research provides a forum for both undergraduate and graduate students to essentially be immersed in another culture and to learn how that culture affects outcomes. Morkisz (2020) described the following, which matches the approach that I have taken in involving students in research:

There was a "case study that might be used as a guideline on how to involve gifted students within such a collaboration with success. The first step was to set-up a frame research agreement between the faculty and a partner from industry. Such collaboration was established between AGH University of Science and Technology and NVIDIA Corporation, global leader in GPU accelerators, high performance computing, and artificial intelligence. It was broadly determined to seek for optimal algorithms for numerical problems, e.g., ordinary differential equations, stochastic differential equations, deep neural networks."

Ashdown (2019) listed several means by which it is both possible and important to incorporate students into international research endeavors. The author described rewards of introducing them to international and culturally based research and provided suggestions based on experiences guiding 26 undergraduates while conducting psychological research in Guatemala. His work resulted in five publications (including nine undergraduate coauthors), various conference presentations, and other ongoing projects with another seven student collaborators (Ashdown, 2019). He listed the following challenges as important to involving undergraduates in international research:
(1) establish local collaborations,

(2) avoid "safari" research (i.e., "scholarship by researchers who lack deep understandings of the cultures they study"),

(3) understand students' cultural and research skills,

(4) get official institutional support for students' travel and work, and

(5) model international research ethics.

Over the years, students working with the Center for Meat Safety and Quality (CMSQ) at Colorado State University (CSU) have had a plethora of opportunities to be involved with international efforts-most to improve trade or address technical issues that essentially prevented trade. As demonstrated by Fields et al. (2018), there is substantial value to the industry in improving both the volume and value of meat exports. Many of these studies involved international travel, whereas several more were the consequences of study to understand and/or provide information impacting an international issue. Many such studies led to publication of refereed scientific papers, whereas many more were sensitive in nature and were not publishedalthough their impacts may have been great. Although the CMSQ conducted several international studies and projects, for purposes of brevity, only a few are described here as examples of how students were involved.

One of the first studies conducted by CMSQ in the mid-1990s involved an effort funded by the beef industry to improve storage and case life of exported whole-muscle beef products. Zerby et al. (1999; Figure 1) set up an effort to supplement feedlot beef cattle with $\alpha$-tocopherol acetate (vitamin E) to reduce oxidation and improve muscle metmyoglobin-reducing power that subsequently were exported to Japan for sale in large Japanese retail

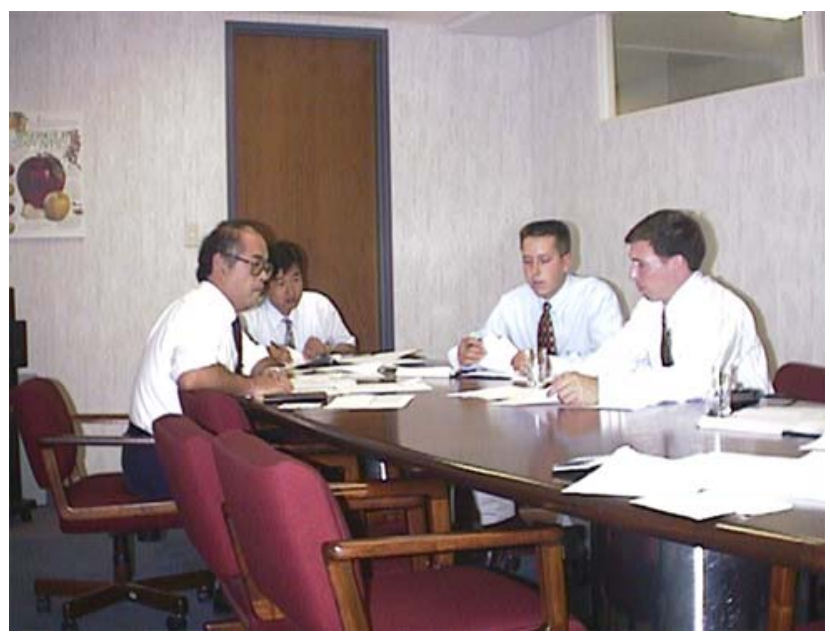

Figure 1. Students conducting interviews at USMEF in Tokyo. 
outlets. Such treatment had been shown to extend the storage life and case life of beef and allow more time for sale to consumers at full value. During the completion of that study, two students (including Dr. Zerby, an American Meat Science Association member) were asked to essentially live in Japan - one in Utsunomiya to the north, and one in Yokohama to the south of Tokyo, respectively. Every day, the students had to collect retail data in the outlets that they were responsible for and bring samples to the "laboratory" for additional evaluation (really, a kitchen that we could use in the United States government's Agricultural Trade Office in Tokyo). The experience allowed the students to become immersed in the cultures where they lived and learn about the workings of the US Meat Export Federation (USMEF) and Embassy offices in Tokyo.

Another series of studies (Vonada et al. 2000, 2001; Figure 2) allowed several students to spend multiple, but shorter, times in South Korea. Data were gathered to assess preferences for pork quality attributes. Funded by the US pork industry, the first phase of the study was to assess potential factors affecting demand for US pork in Korea. The second was to quantify using a structured attribute preference rating system at the Seoul Food Show those characteristics that would improve pork export volume. Students were involved by traveling to Korea, collecting in-store data, and conducting translated interviews during the first phase. In the second phase, they worked in the USMEF booth at the Seoul Food Show during the second phase of data collection. In both cases, these were unique opportunities to interact with and learn about differences in preferences because of differences in culture.

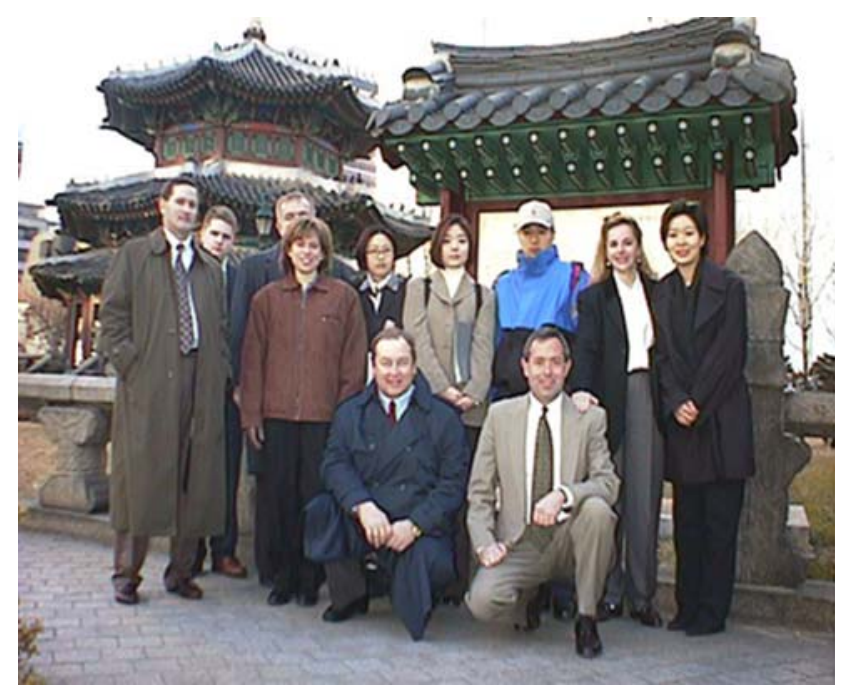

Figure 2. Data collection team in South Korea.
Vote et al. (2009) reported on the study to implement an instrument grading system into the marketing systems of Uruguay. In that study, undergraduate and graduate students made multiple trips to Uruguay to collect both compositional and quality information that were then predicted by an evolving classification system used by the Uruguayan Instituto Nacional de Carnes (National Meat Institute) and Ministry of Agriculture. Students were exposed to significant cultural flavors as they spent many weeks traveling the Uruguayan countryside.

On behalf of the pork industry, Murphy et al. (2015) conducted an economic study to ascertain the willingness-to-pay and ranking of quality attributes for US pork exported to Asia and Mexico. Data collection involved substantial travel of multiple students; students collected data by eliciting structured feedback via programmed and translated face-to-face interviews in those countries. The Murphy et al. (2015) study became important as the US pork industry implemented policies that now result in approximately $25 \%$ of production volume being exported, a number once thought to be outrageous. During this study, at least 12 differing students were exposed to a range of cultures and value systems- something that has benefited them throughout their subsequent careers.

Another example of a study that involved both travel and international collaboration was that reported by Luzardo et al. (2016a, 2016b). Efforts to improve the storage life of fresh beef both produced in the US and Uruguay resulted in a partnership with Instituto Nacional de Investigació Agropecuaria (INIA) in Uruguay and a major meat packaging company in the US. Products were obtained in a standardized fashion from both the production systems in Uruguay and the US, shipped to CMSQ in the US, and then evaluated for both features that affected shelf life as well as methods for improving shelf life. The students involved in these studies were exposed to the vast impacts that can be imposed on meat quality via differences in geographical and cultural differences in production systems.

Still other research projects (and quite a few, for sensitivity reasons, are not listed here) did not require international travel experience but led to important findings and the study by students of both international cultures and issues. Bowling et al. (2008), Davis and Belk (2018), Davis et al. (2019, 2020), Delmore et al. (1999, 2000), Huerta-Leidenz et al. (2016), and Rovira et al. $(2007,2019)$ all reported data that had substantial international ramifications, from addressing bovine spongiform encephalopathy ramifications to reducing 
the risk of foodborne illness in exported products, among other issues. All addressed technical barriers to trade faced by exporters at the time, and many of these studies (along with others) have resulted in expanded market access to US products. Students that worked on such studies have frequently ended up in careers targeting the export of US (and other countries') agricultural products.

\section{Involvement of Students Through Meetings}

Meat science graduate students who have been enrolled in the CMSQ at CSU, although it is clearly not the only opportunity at CSU or other universities, have benefited most by presenting at the International Congress on Meat Science and Technology (ICoMST). Several presentations at ICoMST have allowed our students to experience a number of countries, along with their culture, by participating in the chance to visit each for a week during the meeting. For example (and clearly not the only example), Weinroth et al. (2018) presented cutting-edge and "first-of-its-kind" research results at the ICoMST addressing metagenomics in issues surrounding food safety and antimicrobial resistance, a talk that essentially described what food safety and microbiology might look like in the near future. Furthermore, participation in the premeeting Ph.D. program that is normally tied to ICoMST has proven valuable to our students. The preprogram Ph.D. course allows students in meat science to meet others with the same passion around the world, allows them to discuss and develop new thinking regarding study designs, provides for the development of new research ideas, and basically assists them as they more rapidly become true scientists. This mechanism has proven multiple times to provide an unparalleled opportunity for research-minded graduate students.

\section{Field Trips, Exchange Programs, Capacity Building, and Internships}

Today, there are literally thousands of structured programs allowing students to gain international experience as a component of their education. Many of these are sanctioned by university international programs, whereas many additional options exist that may not be sanctioned by universities. Study abroad, Semester at Sea, etc., offer opportunities to students (mostly undergraduates and graduating seniors) to travel the world. Some of these programs are geared towards providing an "experience" while resulting in foreign assistance/development and personal growth. Others require involvement after graduation (Table 1). Likewise, many universities have an International Memorandum of Understanding in place with foreign institutions that can facilitate both student exchanges and collaborative research. For disciplinerelated student opportunities, these make a good option for facilitated education and improved personal growth.

The CMSQ at CSU established several disciplinerelated opportunities for students to participate in exchange and internships, including with the USMEF, Lincoln University (New Zealand), INIA-Uruguay, Charles Sturt University (Australia), the University of Western Australia, Southwest University (China), the University of Glasgow, and others. No two of the agreements are exactly the same, but they offer opportunities for undergraduate students to gain international experience. It is clear that many Land Grant institutions provide similar opportunities, but it is fundamentally important to encourage participation in such programs.

The Department of Animal Science at CSU has also encouraged international internships, whether at a company or with an institution in another country. My daughter participated in one of these internships by spending a summer with a beef company in Uruguay; the benefits were difficult to quantify. Programming at CSU always encourages undergraduate students to take advantage of new opportunities and tries to convince them that it is important to leave their comfort zone and explore the world-albeit safely.

Table 1. Selected examples of international opportunities for United States students and recent graduates outside of university offerings

\begin{tabular}{|c|c|}
\hline Entity Offering & Name of Program \\
\hline American Meat Science Association & $\begin{array}{l}\text { Robert Cassens Ph.D. Scholar } \\
\text { Award }\end{array}$ \\
\hline American Meat Science Association & $\begin{array}{l}\text { The Hunter International } \\
\text { Travel Award }\end{array}$ \\
\hline American Meat Science Association & Kinsman International Award \\
\hline $\begin{array}{l}\text { USDA Animal and Plant Health } \\
\text { Inspection Service }\end{array}$ & $\begin{array}{l}\text { William F. Helms Internship } \\
\text { Program }\end{array}$ \\
\hline USDA Foreign Agricultural Service & International Agriculture Intern \\
\hline USDA Foreign Agricultural Service & $\begin{array}{l}\text { Borlaug-Ruan International } \\
\text { Internship }\end{array}$ \\
\hline $\begin{array}{l}\text { Council for International Exchange of } \\
\text { Scholars }\end{array}$ & Fulbright US Student Program \\
\hline $\begin{array}{l}\text { Council for International Exchange of } \\
\text { Scholars }\end{array}$ & Fulbright Postdoctoral Award \\
\hline Peace Corps & Corps Volunteer \\
\hline
\end{tabular}

USDA = US Department of Agriculture. 


\section{Pedagogy Designed to Instill International Knowledge}

Green (2019) stated that "The concept of engagement has much to offer the field of international education. Ideally, universities provide all students with opportunities to develop the knowledge, skills, and attributes that will prepare them for life and work in our globalized world." So, our opinion has been that the best pedagogy involves students at the heart of the international experience-whether in person or online.

Very recently, CMSQ initiated a new course at CSU that is taught by Phil Seng, former CEO for the USMEF and Affiliate Professor, and Dr. Brad Morgan, Professor (ANEQ 480: Exploring Meat Export Opportunities). Given the status of population growth and global trade, we feel that we would be remiss if we did not provide students with at least an insight into the importance of global trade and how to be successful in a global market. Our longer-term goal is to provide an experiential learning opportunity to students that involves the actual trading of meat and meat byproducts.

Although launched during the pandemic, the ANEQ 480 course was innovative. It resulted in lectures explaining how to open a new market, how to promote products in that market, what happens when a crisis ensues, how to understand the importance of trade negotiations, and how to determine which markets fit which products. Then, the instructors used electronic technologies (i.e., Zoom) to allow the students to interact with experts in these topic areas all over the world. Such experts included, as just an example, Laurie Bryant (Executive Director of the Meat Importers Council, Burke, VA), Susumu Harada (Consultant, Harada \& Associates, Tokyo, Japan), Joel Haggard (USMEF Senior Vice President, Meat Marketing, ASIAN Nations, Hong Kong, China), and others. All have global recognition for their knowledge in certain markets, and we felt that this was a great new opportunity for undergraduate and graduate students alike.

\section{Literature Cited}

Ashdown, B. K. 2019. Involving undergraduates in publishable international research: experiences in Latin America. Front. Psychol. 10:656. https://doi.org/10.3389/fpsyg.2019.00656.

Bowling, M. B., R. S. Yemm, K. E. Belk, J. N. Sofos, G. C. Smith, and J. A. Scanga. 2008. An evaluation of central nervous system cross-contamination due to carcass splitting in commercial beef-packing plants. J. Food Prot. 71:83-92. https://doi.org/10.4315/0362-028x-71.1.83.

Davis, H. E., and K. E. Belk. 2018. Managing meat exports considering production technology challenges. Anim. Frontiers 8:23-29. https://doi.org/10.1093/af/vfy007.

Davis, H. E., C.-D. Badger, P. Brophy, I. Geornaras, T. J. Burnett, J. Scanga, K. Belk, and J. Prenni. 2019. Quantification of ractopamine residues on and in beef digestive tract tissues. J. Anim. Sci. 97:4193-4198. https://doi.org/10.1093/jas/skz263.

Davis, H. E., I. Geornaras, V. Lindstrom, J. M. Chaparro, M. N. Nair, R. J. Delmore, T. E. Engle, K. E. Belk, and J. E. Prenni. 2020. Effects of differing withdrawal times from ractopamine hydrochloride on residue concentrations of beef muscle, adipose tissue, rendered tallow, and large intestine. PLOS ONE 15: e0242673. https://doi.org/10.1371/journal.pone.0242673.

Delmore, R. J., Jr., J. N. Sofos, G. R. Schmidt, K. E. Belk, W. R. Lloyd, and G. C. Smith. 2000. Interventions to reduce microbiological contamination of beef variety meats. J. Food Prot. 63:44-50.

Delmore, R. J., Jr., J. N. Sofos, K. E. Belk, W. R. Lloyd, G. L. Bellinger, G. R. Schmidt, and G. C. Smith. 1999. Good manufacturing practices for improving the microbiological quality of beef variety meats. Dairy, Food Env. San. 19:742-752.

Fields, K. H., D. A. Therrien, D. Halstrom, J. Haggard, and P. Clayton. 2018. International beef trade: A value proposition. Anim. Frontiers 8:16-22. https://doi.org/10.1093/af/vfy013.

Green, W. 2019. Guest Editorial. Engaging students in international education: Rethinking student engagement in a globalized world. J. Stud. Int. Educ. 23:3-9. https://doi.org/10.1177/ 1028315318814197.

Huerta-Leidenz, N., S. T. Howard, A. Ruíz Flores, T. M. Ngapo, and K. E. Belk. 2016. A survey of Mexican retail chain stores for fresh U.S. pork. Meat Sci. 119:165-173. https://doi.org/ 10.1016/j.meatsci.2016.04.038.

Luzardo, S., D. R. Woerner, I. Geornaras, T. E. Engle, R. J. Delmore, A. M. Hess, and K. E. Belk. 2016a. Effect of packaging during storage time on retail display shelf life of strip loins from two different beef production systems. J. Anim. Sci. 94:2624-2636. https://doi.org/10.2527/jas.2016-0305.

Luzardo, S., D. R. Woerner, I. Geornaras, T. E. Engle, R. J. Delmore, A. M. Hess, and K. E. Belk. 2016b. Effect of packaging during storage time on retail display microbial populations of beef strip loins from two different production systems. J. Anim. Sci. 94:2614-2623. https://doi.org/10.2527/jas.2016-0290.

Morkisz, P. 2020. Involving students in research collaboration with industrial global leader. Teaching mathematics in higher education and working with gifted students in contemporary context. In: M. E. Lustenkov, editor, Proceedings of the International Scientific Practical Conference. Ministry of Education of the Republic of Belarus, Mogilev, Belorus.

Murphy, R. G. L., S. T. Howard, D. R. Woerner, D. L. Pendell, C. L. Dixon, T. L. Desimone, M. D. Green, J. L. Igo, J. D. Tatum, and K. E. Belk. 2015. Definition, willingness-to-pay, and ranking of quality attributes of U.S. pork as defined by importers in Asia and Mexico. J. Anim. Sci. 93:433-441. https://doi. org/10.2527/jas.2014-8102.

Rovira, P. J., J. A. Scanga, T. Grandin, K. L. Hossner, R. S. Yemm, K. E. Belk, J. D. Tatum, J. N. Sofos, and G. C. Smith. 2007. 
Central nervous system tissue contamination of the circulatory system following humane cattle stunning procedures. Food Prot. Trends 27:524-529.

Rovira, P., T. McAllister, S. M. Lakin, S. R. Cook, E. Doster, N. R. Noyes, M. D. Weinroth, X. Yang, J. K. Parker, C. Boucher, C. W. Booker, D. R. Woerner, K. E. Belk, and P. S. Morley. 2019. Characterization of the microbial resistome in conventional and "raised without antibiotics" beef and dairy production systems. Front. Microbiol. 10:1980. https://doi. org/10.3389/fmicb.2019.01980.

Vonada, M. L., B. S. Bidner, K. E. Belk, F. K. McKeith, W. R. Lloyd, M. E. O'Connor, and G. C. Smith. 2000. Quantification of pork belly and Boston butt quality attribute preferences of South Korean customers. J. Anim. Sci. 78:2608-2614. https://doi.org/10.2527/2000.78102608x.

Vonada, M. L., B. S. Bidner, K. E. Belk, F. K. McKeith, W. R. Lloyd, M. E. O'Connor, and G. C. Smith. 2001. Factors influencing consumer demand for U.S. pork exported to the Republic of Korea (South Korea). J. Anim. Sci. 79:907911. https://doi.org/10.2527/2001.794907x.

Vote, D. J., M. B. Bowling, B. C. N. Cunha, K. E. Belk, J. D. Tatum, F. Montossi, and G. C. Smith. 2009. Video image analysis as a potential grading system for Uruguayan beef carcasses. J. Anim. Sci. 87:2376-2390. https://doi.org/10.2527/jas.20091791.

Weinroth, M. D., B. C. Britton, and K. E. Belk. 2018. Genetics and microbiology of meat. Meat Sci. 144:15-21. https://doi.org/ 10.1016/j.meatsci.2018.04.017.

Zerby, H. N., K. E. Belk, J. K. Ahola, J. N. Sofos, D. M. Schaefer, J. B. Morgan, and G. C. Smith. 1999. Effects of muscle a-tocopherol level and surface microbiological contamination on retail caselife of fresh beef from the US, Japan and Australia. Meat Sci. 52:111-118. https://doi.org/10.1016/ s0309-1740(98)00155-7. 